\title{
Brněnské kolokvium o Dostojevském
}

\author{
Ivo Pospíšil (Brno)
}

V návaznosti na projekt mezinárodních doktorských škol, který brněnští literární vědci, učitelé, a hlavně doktorandi zahájili kolokviem o N. S. Leskovovi, z něhož vyšel v zahraničí velmi ceněný publikační výstup, ${ }^{1}$ uspořádal Ústav slavistiky Filozofické fakulty Masarykovy univerzity dne 9. 10. 2018 kolokvium o F. M. Dostojevském. Za př́tomnosti představitelů Filozofické fakulty MU se na kolokviu prezentovali dostojevskologové a jejich doktorandi z České republiky, Slovenska, Polska, Ukrajiny a Litvy, aby analyzovali výsledky dostojevskologie ve svých zemích, demonstrovali výsledky svých připravovaných disertací a objevovali nové souvislosti díla autora, který je patrně nejvýznamnějším světovým romanopiscem vůbec se silným vlivem na světovou literaturu 20. a 21. století.

Olha Červinskaja z univerzity Černovice (Ukrajina, ukraj. Černivci, rus. Černovcy, rumunsky Cernăuți, pol. Czerniowce, německy Czernowitz, jiddiš Че́рновиц - טשערנזוויץ), která nás nutí vzpomenout na složité dějiny Bukoviny a jejího hlavního města včetně výrazné české účasti na jejím rozvoji, i na české práce o Juriji Fed'kovyčovi ${ }^{2}$, vystoupila s referátem Virsavia (Batšeba,

1 POSPÍŠIL, Ivo (ed.): Leskov $i$ vokrug. Konteksty tvorčestva $i$ sostojanije sovremennogo leskovovedenija. Brno: Ústav slavistiky Masarykovy univerzity, 2018.

2 Viz KRHOUN, Mečislav: Básnické dilo Jurije Fed'kovyče. Brno: UJEP, 1973. Viz o tom naše studie: A Chapter from Brno Ukrainian Literary Studies: the Creative Activity of $\mathrm{Me}$ čislav Krhoun and His Book on Jurij Fed'kovyč. In: Pagine di ucrainistica europea. A cura di Giovanna Brogi Bercoff, Giovanna Siedina. Edizioni dell'Orso, Alessandria, 2001, s. 83-90; Kapitola z dějin brněnské ukrajinistiky: Kniha Mečislava Krhouna o Juriji Fed'kovyčovi. Univerzitní noviny, 2000, č. 2, s. 14-16; Jubileum slavisty (Mečislav Krhoun, 1907-1982). Universitas, 1997, č. 1, s. 25-26; Koncepcija tvorčestva Jurija Fed'koviča v monografii Mečislava Krgouna v kontekste brnenskoj literaturovedčeskoj slavistiki. In: Galicja 1916: Plus/minus dziesięć lat. Przestrzenie dyskursów: historia, literatury, kultury, język. Redakcja tomu Andrzej Borkowski - Roman Mnich. Kolegium Galicyjskie,
Betsabé) jako klićové slovo románu Výrostek. Miluša Bubeníková a Radka Hř́bková (Praha) analyzovaly činnost obnovené české Společnosti Dostojevského (Zdroje, osobnosti, milniky, perspektivy). Slovenská rusistka, která se ve stopách svého otce Andreje Červeňáka zabývá F. M. Dostojevským a M. Bulgakovem, vyložila jeho antropologickou koncepci Dostojevského, Radka Hříbková (Praha) poté pojednala o symbolice dětských gest a mimiky v tvorbě F. M. Dostojevského.

Ingrida Kisieliute (Vilnius) se v objevném příspěvku zabývala ekonomickým aspektem díla Dostojevského (Перспективы изучения твориества Ф. М. Достоевского сквозъ экономическую призму: Сколько? Кому? И ито это значит?); doktorandi O. Červinské, a to Roman Dzyk, Natalija Nikorjak a Julija Isapčuk se zabývali různými tématy: Roman Dzyk zevrubně analyzoval ukrajinskou dostojevskologii, Natalija Nikorjak pojednala o seriálu Dostojevskij a Julija Isapčuk se zabývala monologem knížete Myškina. Nakonec promluvili hostitelé a organizátoři kolokvia. Lenka Paučová, která se v disertaci zabývá $D e-$ nikem spisovatele a jeho souvislostmi, poukázala zde na místo Deniku spisovatele ve východoslovanských encyklopediích a autor této zprávy pojednal o "prokletém“ dědictví Dostojevského v kontextu někdy pocitované krize v působení Dostojevského na současný globalizovaný literární svět.

Kolokvium ve svých různých projevech manifestovalo fakt, že dílo Dostojevského stále žije, všelijak interpretováno a z různých zorných úhlů „natáčeno“, i když ideová a tvarová východiska spisovatele mají v současné literatuře a její dnešní podobě stále těžší úlohu se prosadit. Je možné

Instytut Kultury Regionalnej i Badań Literackich im. Franciszka Karpińskiego, Państwowy Uniwersytet Pedagogiczny im. Iwana Franki w Drohobyczu. Siedlce: Wydawnictwo Naukowe IKR(i)BL, 2018, s. 147-159. 
trvat na tradičním výkladu autora a úporně v něm nacházet nové vazby $\mathrm{k}$ současnosti (tedy spíše než dílo Dostojevského ožívá pod jeho tlakem okolní realita) nebo se je snažit interpretačně modernizovat nebo ještě spíše postmodernizovat, a tak přiblížit dnešním proudům a dnešnímu chápání literatury. Osobně bych byl pro první řešení, sice nekomfortní, ale o to trvalejší. Dílo Fjodora Dostojevského, stejně jako Shakespeara nebo Goetha, trvá ve svých hodnotách, které samy vyvolávají nové a nové konotace, vytvářejíce nové valence a celky, které ještě mohou překvapit. V Rusku i jinde o estetické hodnotě díla Dostojevského nepochybují a vydavatelský a interpretační zájem o tohoto autora, stejně jako činnost různých společností Dostojevského, o tom výmluvně svědčí.

Budovaná tradice brněnských rusistických kolokvií-doktorandských škol má tak své pokračování.

\section{prof. PhDr. Ivo Pospíšil, DrSc.}

Ústav slavistiky

Filozofická fakulta, Masarykova univerzita

Arna Nováka 1, 60200 Brno, Česká republika

ivo.pospisil@phil.muni.cz 